\title{
Effects of Stone Cutting Powder (Al-Khamkha) on the Properties of Self-Compacting Concrete
}

\author{
Manal O. Suliman, Hesham Alsharie, Yasser I. O. Yahia, Talal Masoud \\ Civil Engineering Department, College of Engineering, Jerash University, Jerash, Jordan \\ Email: Manal2015sd@gmail.com
}

How to cite this paper: Suliman, M.O., Alsharie, H., Yahia, Y.I.O. and Masoud, T. (2017) Effects of Stone Cutting Powder (Al-Khamkha) on the Properties of SelfCompacting Concrete. World Journal of Engineering and Technology, 5, 613-625. https://doi.org/10.4236/wjet.2017.54052

Received: September 11, 2017

Accepted: October 20, 2017

Published: October 24, 2017

Copyright $\odot 2017$ by authors and Scientific Research Publishing Inc. This work is licensed under the Creative Commons Attribution International License (CC BY 4.0).

http://creativecommons.org/licenses/by/4.0/

\begin{abstract}
Most of the construction materials research now concerns on investigation of construction materials that is locally produced at a rate and cost compatible with the pace of construction. The present paper is concerned with investigation of fresh and hardened properties of self-compacting concrete (SCC) produced from local available materials in JORDAN. The produced SCC contains the local stone cut waste powder which is called Al-KHAMKHA in JORDAN with different replacement of $(0 \%, 10 \%$, and $25 \%)$ of fine silica aggregate; the study also investigates the effects of SP33 super plasticizer which is used by different doses $(1 \%, 1.5 \%$ and $2 \%)$ for cement. The slump flow and the compressive strength of SCC were studied and the experimental results indicate the possibility of using Al-KHAMKHA in the production of SCC as the results showed that the compressive strength of the SCC with $10 \%$ replacement by al-khamkha together with 1\% SP33 super plasticizer was higher compared to pure SCC without al-khamkha; the results also showed that as al-khamkha content increased the slump flow decreased.
\end{abstract}

\section{Keywords}

Al-Khamkh, Compressive Strength, Self Compacting Concrete, Stone Powder, SP33 Super Plasticizer

\section{Introduction}

Marble and building stones are commonly used in the construction of residential houses and public buildings, during the last decades the natural building stone industry has grown significantly, and recently, marble production contributes approximately $66 \%$ to industrial exports of gross national exports in Jordan [1].

Marble and building stones are produced by taking rock from the earth and reducing it to the required shapes and sizes for construction and this process re- 
sults in producing solid, powder, and slurry wastes with a wide range in quantity [2]. The management of marble and stone industries waste is less and the waste directly discharges in open areas causing serious problems relating to environmental pollution. With increasing demand for marble and stone building materials large quantities of industrial wastes are generated; these wastes may be recycled in one way or another in construction work; when this is the case there will be no problem of stone waste disposal [3].

Construction materials properties changed considerably as the design of buildings developed this create continuous demand for new building material to meet the new requirements for the construction projects such as SCC which was first developed in 1988 to achieve durable concrete structures [4] since then this concrete is widely used in the construction industry and various investigation and studies have been carried out. Self-compacting concrete (SCC) is a very useful concrete in the construction sector because it is a fluid, high strength concrete that can flow and be compacted with little or no vibration under its own weight without segregation and it is self-leveling concrete.

Flow property is very important for SCC which allows the SCC to be suitable for placing concrete in difficult service conditions like congested steel, and difficult formwork shapes, where access is difficult. Thus SCC saves time, labor, equipment requirements and formwork damage [4].

The construction materials researchers now face the challenge of recycling of different industrial wastes into construction materials especially the locally produced wastes and because of local variations in properties of available materials the purpose of this paper is to investigate the SCC properties containing locally produced stone cut powder Al-KHAMKHA as replacement of fine silica aggregate along with the effect of different doses of (SP33) superplasticizer.

Utilization of al-khamkha in construction sector is essential in order to minimize this waste and help in environmental prevention. Moreover, it is an alternative material to replace natural sand and silica materials. This study supports the sustainable use of natural resources and overcome the negative idea of al-khamkha and thus considers it as a resource to be used in construction sector in Jordan.

\section{Literature Review}

Kishan P. Pala et al. (2015) [5] used the marble powder and fly ash as partial replacement of cement in SCC mix. Fresh property such as filling ability and passing ability and hardened property like flexural strength, compressive strength and split strength were investigated. The results indicate an improvement in the filling ability and passing ability by use of $10 \%$ waste marble powder and $25 \%$ fly ash.

Ranjodh Singh et al., (2013) [6] carried out an experimental study of various performance based characteristics of self compacting concrete with different proportions of brick dust and marble powder as fine aggregate replacement. In this study an effort has been made to evaluate the usefulness of brick kiln dust 
and marble powder both of which are waste material to produce cost effective self compacting concrete. Good hardened properties were achieved for the concretes with $25 \%$ marble powder which can be considered as the optimum content for high compressive strength.

M. Shahul Hameed, et al. (2012) [7] studied the effect of addition of crushed rock dust and marble sludge powder on the strength and durability of SCC. Based on the results it is confirmed that compressive strength increases with increase in percentage replacement of marble sludge powder up to $15 \%$ of crushed rock dust in place of fine aggregate. It is found that split tensile strength is directly proportional to the compressive strength. The highest electrical resistivity values were obtained for normal concrete with $100 \%$ crushed rock dust and significant increase in resistivity values for SCC.

Bouziani et al. (2011) [8] made an investigation on Self-compacting sand concrete (SCSC) mixtures with different content of marble powder. Mini-slump flow, the V-funnel flow time and viscosity tests were carried out on the fresh concrete. It was concluded that the increase of marble powder content in SCSC, from $150 \mathrm{~kg} / \mathrm{m}^{3}$ to $350 \mathrm{~kg} / \mathrm{m}^{3}$, improves the properties at fresh state by decreasing v-funnel flow time (from $5 \mathrm{~s}$ to $1.5 \mathrm{~s}$ ) and increasing the mini-cone slump (from $28 \mathrm{~cm}$ to $34 \mathrm{~cm}$ ). With $250 \mathrm{~kg} / \mathrm{m}^{3}$ of marble powder, SCSC have the highest initial viscosity, compared to the marble powder contents of $150 \mathrm{~kg} / \mathrm{m}^{3}$ and $350 \mathrm{~kg} / \mathrm{m}^{3}$. In other hand, the 28 -days compressive strength decreases with an increase of marble powder content.

\section{Experimental Work Plan}

\subsection{Materials}

The main parameter taken into consideration in this work were, dosage of a super plasticizer admixture (SP33) and the percentage of fine silica replacement by al-khamkha.

All types of cement can be used for SCC mixtures, for all mixes in this study locally produced ordinary portland cement, conforming to ASTM Type-1 standards, was used. Available natural silica sand is used as fine aggregate, and natural available coarse aggregate with $20 \mathrm{~mm}$ maximum size is used.

Chemical admixtures are important and necessary components for any SCC. The chemical Floret SP33 superplasticizing admixture based on viscosity enhanced admixture was used with different dosages as a water-reducing agent to improve the workability. Table 1 gives the properties of SP33.

Table 1. Technical properties of SP33 @ 250C.

\begin{tabular}{cc}
\hline Color & Brown liquid \\
\hline Freezing point & $-2 \mathrm{C}$ \\
Specific gravity & $1.19 \pm 0.02$ \\
Chloride content: BS 5075 & Nil \\
Air entrainment & Typically less than 2\% additional air is entrained \\
& above control mix at normal dosages \\
\hline
\end{tabular}


Stone cut powder (al-khamkha) obtained from the discharge point of a stone-cutting plant in JERASH-JORDAN was oven dried and used in SCC mixtures without any more processing. The engineering properties of stone cutting slurry is presented in Tables 2-4.

\subsection{Specimens Preparation and Notation}

The pure control concrete mix (without al-khamkha and SP33Admixture) has been designed to obtain 28-day compressive strength of $20 \mathrm{MPa}$. All SCC mixes were designed to develop a 28-day compressive strength of $20 \mathrm{MPa}$, similar to that of the pure control concrete.

Fine silica was replaced with al-khamkha by weight with (10\%, 25\%). SP33 superplasticizer introduced with three different dosages: $1 \%, 1.5 \%$ and $2 \%$ of cement content. The mixtures were designated as PC (pure concrete) and different mixes of $(\mathrm{C}+\% \mathrm{~K}+\% \mathrm{SP} 33)$ (Concrete plus different\% of al-khamkha $+\%$ of SP33 superplasticizer).

The pure concrete mixture proportion was obtained based on ACI211.1 method. All concrete mixtures were prepared in drum mixer, first, the coarse aggregate, silica, and al-khamkha are introduced and one half of mixing water added and drum mixer rotated for two minutes. Next, the cement were introduced with SP33 superplasticizer already mixed in the remaining water and the drum mixer was rotated for 5 minutes, till the homogeneous SCC mix was obtained, then the flow test and the compressive strength test were conducted.

Table 2. Chemical compositions of stone slurry waste samples generated from the different type of stone cutting process.

\begin{tabular}{cccc}
\hline Parameter\% & $\begin{array}{c}\text { Torres, et al. (2004) } \\
\text { Granite slurry \% [9] }\end{array}$ & $\begin{array}{c}\text { Turgut, et al. (2007) } \\
\text { Limestone dust \% [10] }\end{array}$ & $\begin{array}{c}\text { Ferreira, et al. (2004) } \\
\text { Granite slurry \% [1] }\end{array}$ \\
\hline $\mathrm{SiO}_{2}$ & 71.65 & 0.26 & 61.2 \\
$\mathrm{CaO}$ & 1.83 & 56.19 & 6.6 \\
$\mathrm{Fe}_{2} \mathrm{O}_{3}$ & 2.86 & 0.3 & 12.4 \\
$\mathrm{Al}_{2} \mathrm{O}_{3}$ & 14.25 & 0.25 & 12.4 \\
$\mathrm{MgO}$ & 0.86 & 0.0 & 0.4 \\
$\mathrm{LOI} \%$ & 0.1 & 42.56 & 0.68 \\
\hline
\end{tabular}

Table 3. Chemical properties of stone powder waste [12].

\begin{tabular}{ccccccc}
\hline $\begin{array}{c}\text { Type of } \\
\text { stone waste }\end{array}$ & $\begin{array}{c}\text { Calcium } \\
\text { oxide } \% \\
\mathrm{CaO}\end{array}$ & $\begin{array}{c}\text { Silica \% } \\
\mathrm{SiO}_{2}\end{array}$ & $\begin{array}{c}\text { Aluminum } \\
\text { Trioxide \% } \\
\mathrm{Al}_{2} \mathrm{O}_{3}\end{array}$ & $\begin{array}{c}\text { Ferrous } \\
\text { oxide \% } \\
\mathrm{Fe}_{2} \mathrm{O}_{3}\end{array}$ & $\begin{array}{c}\text { Magnesium } \\
\text { oxide \% } \\
\mathrm{MgO}\end{array}$ & $\begin{array}{c}\text { loss on } \\
\text { ignition } \\
\% \text { LOI }\end{array}$ \\
\hline Lime stone waste & 49.9 & 9.92 & 1.06 & 0.404 & 0.2 & 38 \\
\hline
\end{tabular}

Table 4. Physical properties of powder stone waste [13].

\begin{tabular}{cccc}
\hline Type of stone & Specific gravity & Bulk density & color \\
\hline Lime stone & 26.265 & $15.7-17.5$ & White/dirty white \\
\hline
\end{tabular}




\subsection{The Slump Flow}

To evaluating the workability of fresh SCC the slump flow test was used which indicates the free, unrestricted deformability of SCC (filling ability). The slump flow for All SCC mixes was determined following ASTM C 1611/C 1611M. The slump flow test consists of a base plate and slump cone that conforms to ASTM C-143 standard (Figure 1). Unlike the standard slump test, the fresh SCC was measured after the removal of the cone to characterize the flowability of the concrete. The slump cone was completely filled with SCC without consolidation, the cone lifted and the spread of the concrete was measured by measuring the diameter of spread in two perpendicular directions.

The Flow spread $[\mathrm{mm}]$ is the average of the largest diameter of the flow spread $(d \max )$ and the one perpendicular to it (dperp), as shown in Equation (1)

$$
\text { Flow spread }[\mathrm{mm}]=\frac{d \max +d \text { perp }}{2}
$$

The flow spread of SCC typically ranges from 455 to $810 \mathrm{~mm}$ depending on the requirements of the project.

\subsection{Compressive Strength}

Hardened SCC was measured in terms of its performance by means of compressive strength at ages of 7 and 28 days. The 28 day design compressive strength was established as $20 \mathrm{MPa}$ for all SCC mixtures. Following the completion of the flow testing, the SCC was poured into specimens, and placed in order to prepare the samples for the compressive strength testing. For each mix 6 standard cubes $(150 \times 150 \times 150)$ and 6 standard cylindrical concrete samples (with a diameter of $150 \mathrm{~mm}$ and a length of $300 \mathrm{~mm}$ ) were prepared and casted without any vibration or compaction. Specimens were demoulded one day after casting and then cured in water at approximately $20^{\circ} \mathrm{C}$ until testing was carried out at 7 and 28 days age. The average compressive strengths were obtained from three cubes and three cylinders for each batch at each age. The tests were performed in accordance with the ASTM C39 standards. Figure 2 and Figure 3 show the cube and cylinder specimens in Compression testing machine.

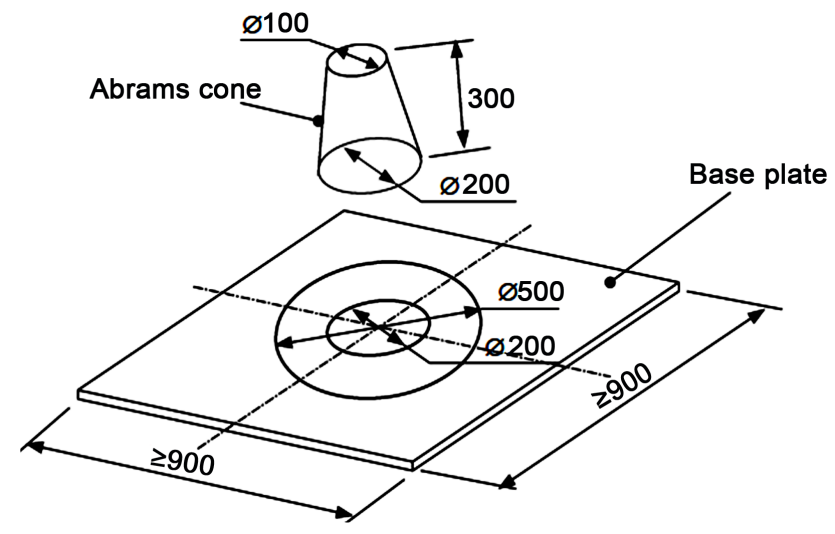

Figure 1. Shapes and dimensions of slump flow for spread test. 


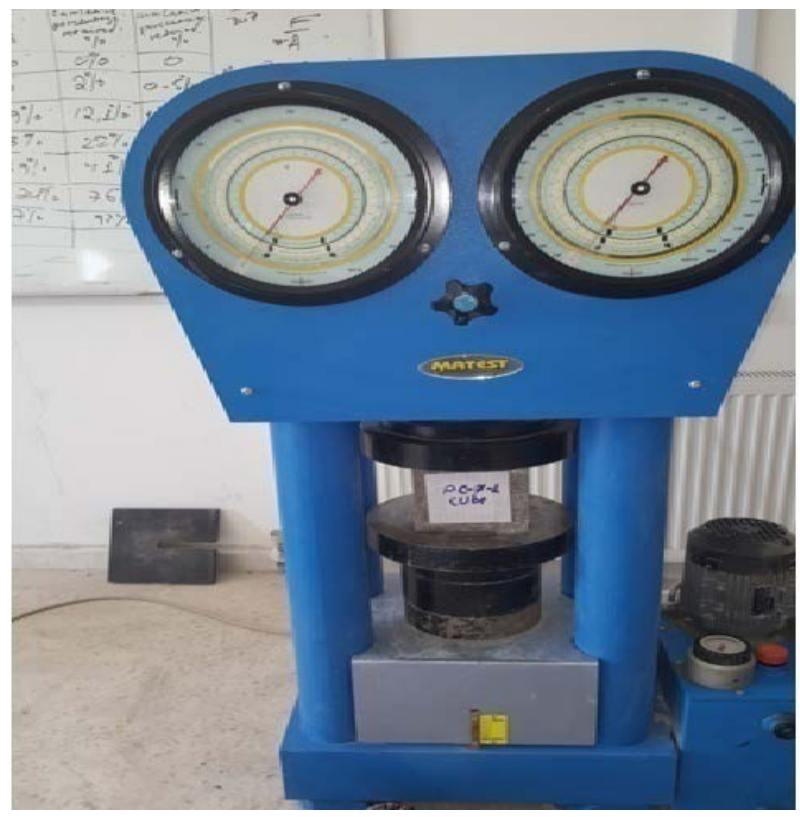

Figure 2. Testing cube specimen.

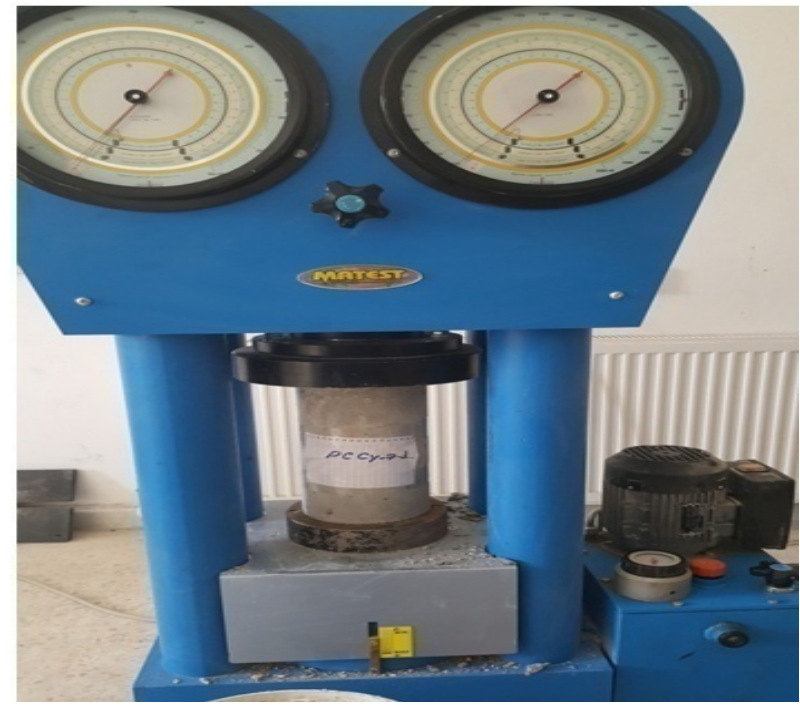

Figure 3. Testing cylindrical specimen.

\section{Results and Discussion}

\subsection{Results of Fresh Properties}

Table 5 lists the average flowability measured for each of the SCC mixtures. Out of all SCC mixes, the mix C $+2 \%$ SP33 had the largest flow and the mix C $+25 \%$ $\mathrm{K}+1 \%$ SP33 had the lowest flow. All SCC mixes without al-khamkha give higher values of slump flow diameter rather than the mixes containing al-khamkha as replacement of silica sand. It was observed that addition of al-khamkha has a significant effect on decreasing the flowability of the SCC. These results may be due to the higher total surface area of al-khamkha compared to the silica sand as fine aggregate. 
Table 5. Slump flow properties of SCC mixes.

\begin{tabular}{cc}
\hline Mix Proportion & Slump Flow $(\mathrm{mm})$ \\
\hline $\mathrm{C}+1 \% \mathrm{SP} 33$ & 500 \\
$\mathrm{C}+1.5 \% \mathrm{SP} 33$ & 620 \\
$\mathrm{C}+2 \% \mathrm{SP} 33$ & 730 \\
$\mathrm{C}+10 \% \mathrm{~K}+1 \% \mathrm{SP} 33$ & 350 \\
$\mathrm{C}+10 \% \mathrm{~K}+1.5 \%$ SP33 & 410 \\
$\mathrm{C}+10 \% \mathrm{~K}+2 \% \mathrm{SP} 33$ & 520 \\
$\mathrm{C}+25 \% \mathrm{~K}+1 \% \mathrm{SP} 33$ & 340 \\
$\mathrm{C}+25 \% \mathrm{~K}+1.5 \% \mathrm{SP} 33$ & 360 \\
$\mathrm{C}+25 \% \mathrm{~K}+2 \% \mathrm{SP} 33$ & 480 \\
\hline
\end{tabular}

In general from Table 5 it can be noticed that, the slump flow diameter increases for all SCC mixtures as a function of the dosage of P33, the SP33 superplasticizer dosage increase the slump flow increase.

Figure 4 and Figure 5 display pictures of two SCC mixes from this study with different content of al-khamkha.

\subsection{Results of Compressive Strength}

The obtained values of pure concrete compressive strength according to the different used percentage of al-khamkha for cube specimens are shown in Figure 6. This figure indicate that, the higher the percentage of al-khamkha the lower the values of compressive strength.

The maximum compressive strength $(21 \mathrm{MPa})$ was achieved by $(\mathrm{C}+10 \% \mathrm{~K})$ concrete mix; it was $6.061 \%$ more than the control mix P.C at 7 days age.

At the age of 28 days, the achieved compressive strength of mixtures ( $\mathrm{C}+10 \%$ $\mathrm{K})$ and $(\mathrm{C}+25 \% \mathrm{~K})$ were $(25.5 \mathrm{MPa})$ and $(21.2 \mathrm{MPa})$, respectively. The percentage increase in compressive strength was $28.8 \%$ and $7.071 \%$ for mixtures $(\mathrm{C}+$ $10 \% \mathrm{~K})$ and $(\mathrm{C}+25 \% \mathrm{~K})$ than P.C control mix.

From the above observations, it is clearly seen that for P.C, al-khamkha substitution should be limited to approximately $10 \%$ for optimal performance.

\subsection{Effects of Al-Khamkha and SP33 on SCC Compressive Strength}

\subsubsection{Results of Compression Test of Cube Specimens}

The values of SCC cube samples compressive strength results at age 7 and 28 days for $10 \%$ and $25 \%$ replacement of fine silica with al-khamkha are shown in Figure 7 and Figure 8.

For comparison purposes, Figure 9 combines the effect of different percentage of replacement into SCC mix on both the 7-days and 28-days compressive strengths for different SP33 doses.

As illustrated in figures, at the age of 7 days compressive strength of PC was (18.7 MPa) and maximum compressive strength (18.7 MPa) was achieved by (C $+10 \% \mathrm{~K}+1 \%$ SP33) mix it was same compressive strength as PC mix. 


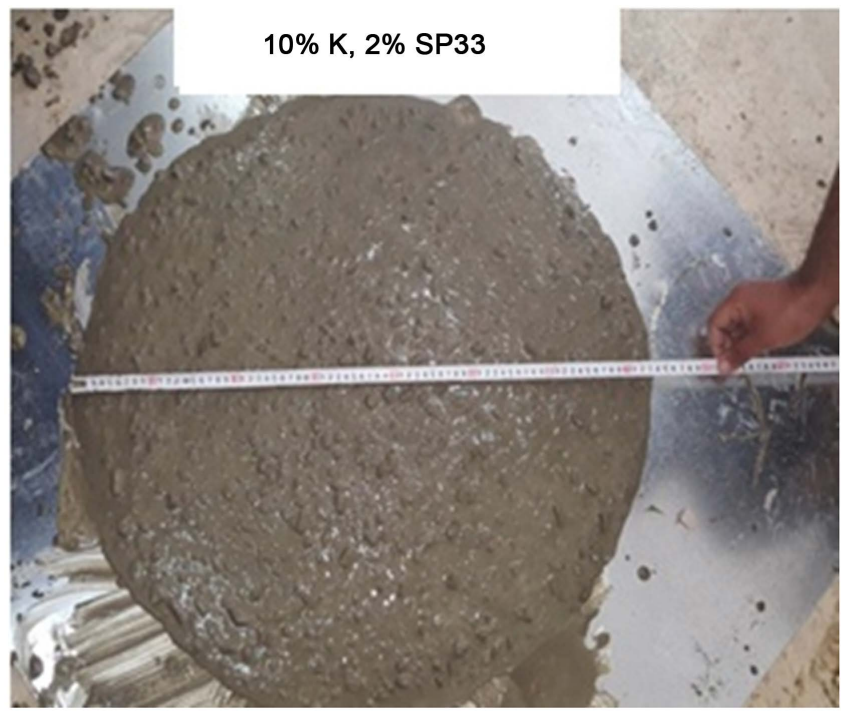

Figure 4. SCC mix with $10 \% \mathrm{~K}+2 \%$ SP33.

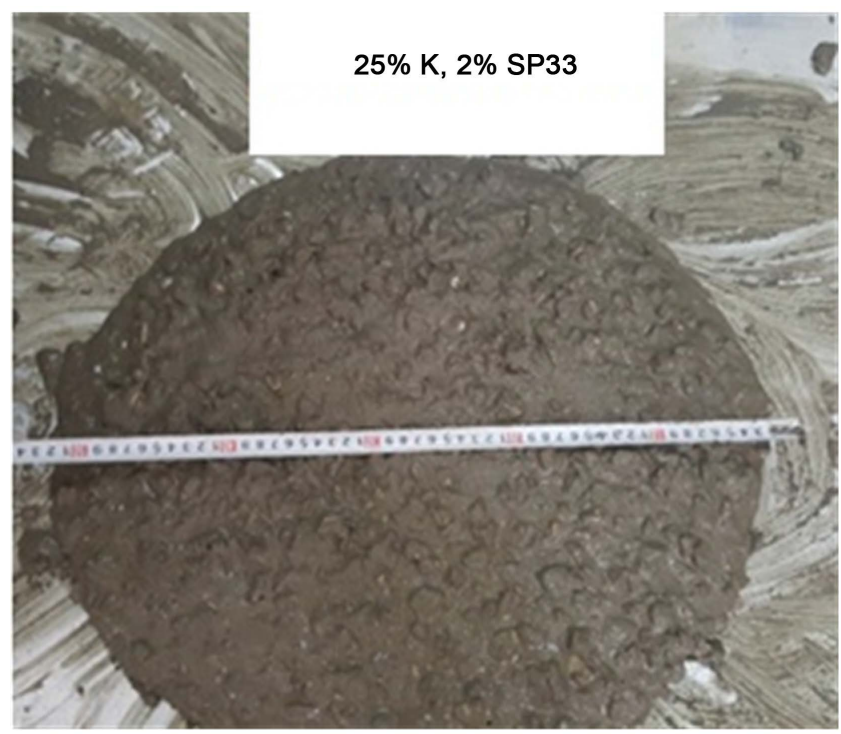

Figure 5. SCC mix with $25 \% \mathrm{~K}+2 \%$ SP33.

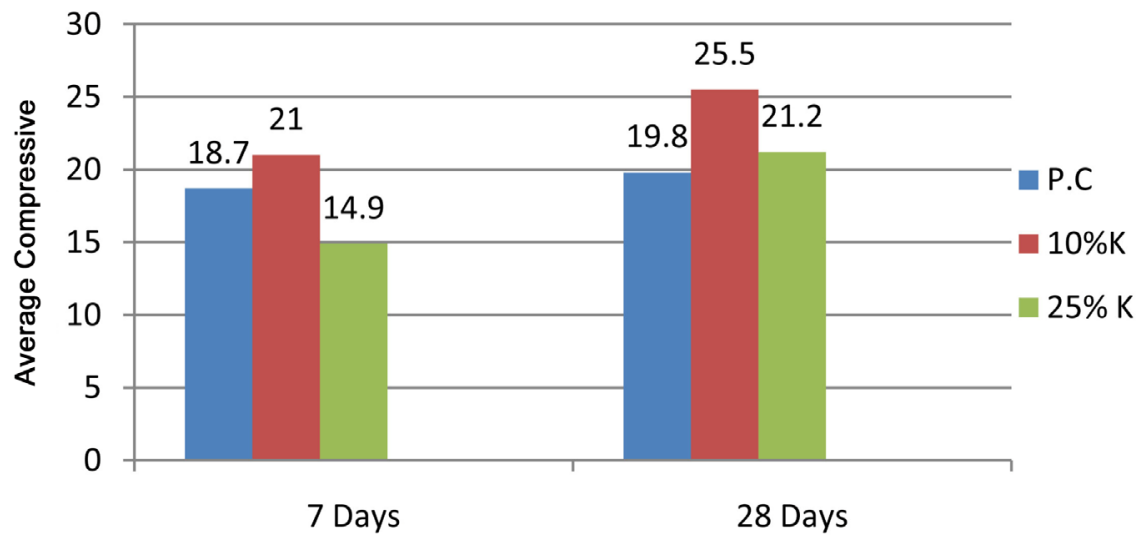

Figure 6. Effect of al-khamkha on compressive strength of pure concrete. 


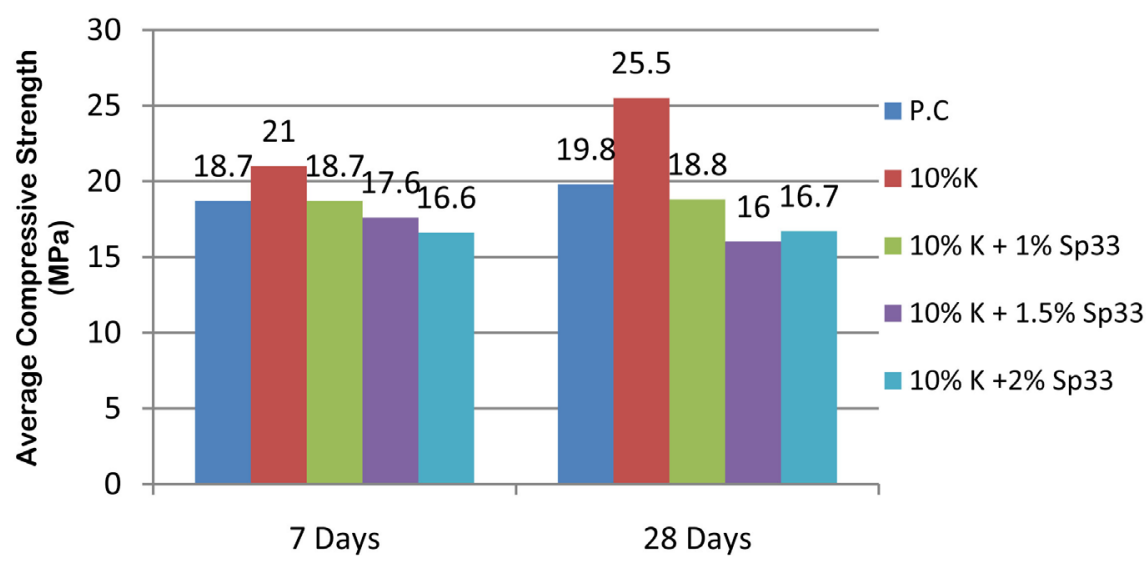

Figure 7. Compressive strength of SCC mixes with $10 \% \mathrm{~K}+$ different $\%$ SP33 dose compared with P.C at age 7 and 28 days for cube specimens.

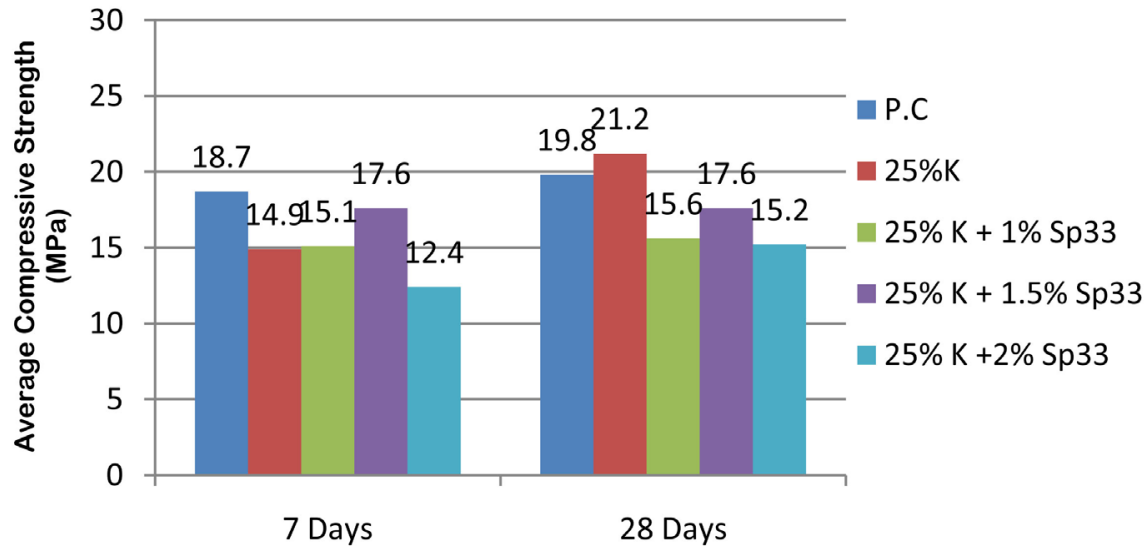

Figure 8. Compressive strength of SCC mixes with $25 \% \mathrm{~K}+$ different $\%$ SP33 dose compared with P.C at age 7 and 28 days for cube specimens.

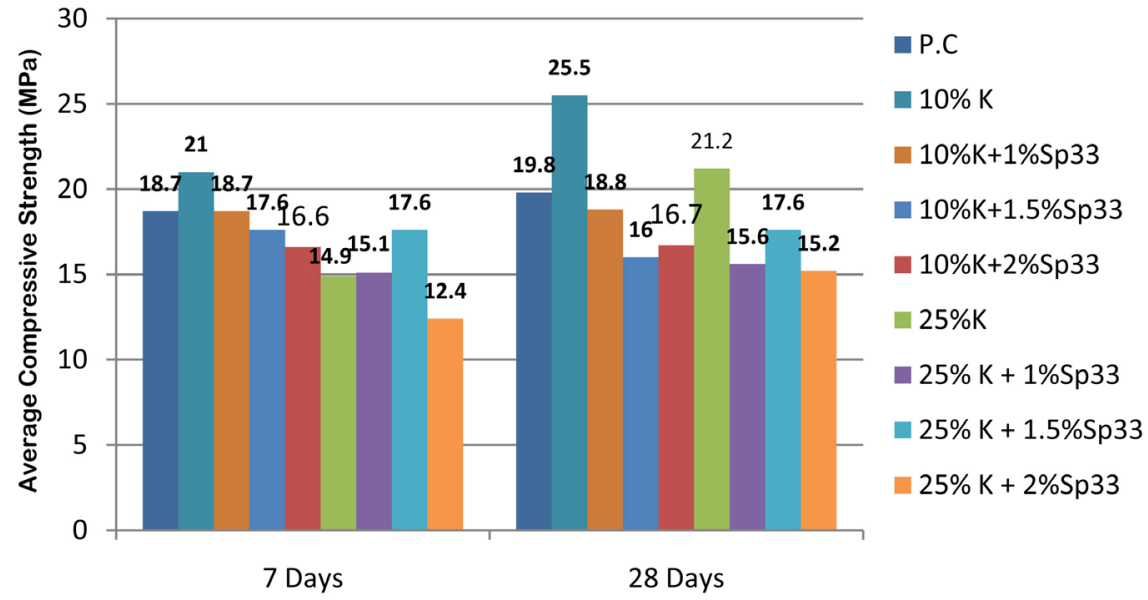

Figure 9. Compressive strength of various SSC mixes with different $\%$ of al-khamkha and different $\%$ SP33 dose at age 7 and 28 days for cube specimens.

At the age of 28 days, compressive strength of P.C was (19.8 MPa) and maximum compressive strength $(18.8 \mathrm{MPa})$ was achieved by $(\mathrm{C}+10 \% \mathrm{~K}+1 \% \mathrm{SP} 33)$ 
mix. The compressive strength is decreased by $5 \%$ than PC mix.

SCC mix with higher the percentage of al-khamkha and higher dose of SP33 $(\mathrm{C}+25 \% \mathrm{~K}+2 \% \mathrm{SP} 33)$ had lowered compressive strength value.

These results imply that SCC with low percentage of al-khamkha replacement exhibits higher compressive strength.

\subsubsection{Results of Compression Test of Cylindrical Specimens}

Figure 10 and Figure 11 show also how compressive strength changed with a different percentage of replacement of silica with al-khamkha along with different doses of SP33 for cylindrical samples.

Figure 12 shows the effects of different percentage of al-khamkha replacement on compressive strength.

As can be seen from the figures, at the age of 7 days, compressive strength of $\mathrm{PC}$ was $(18.7 \mathrm{MPa})$ and maximum compressive strength is $(15.8 \mathrm{MPa})$ was

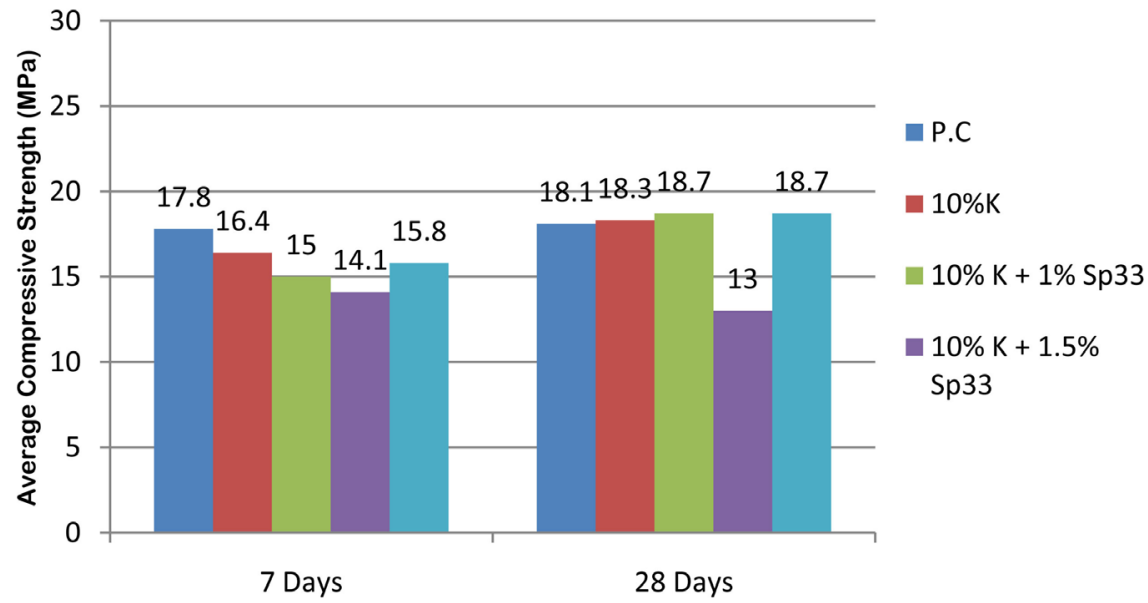

Figure 10. Compressive strength of SCC mixes with 10\% K + different \% SP33 dose compared with P.C at age 7 and 28 days for cylindrical specimens.

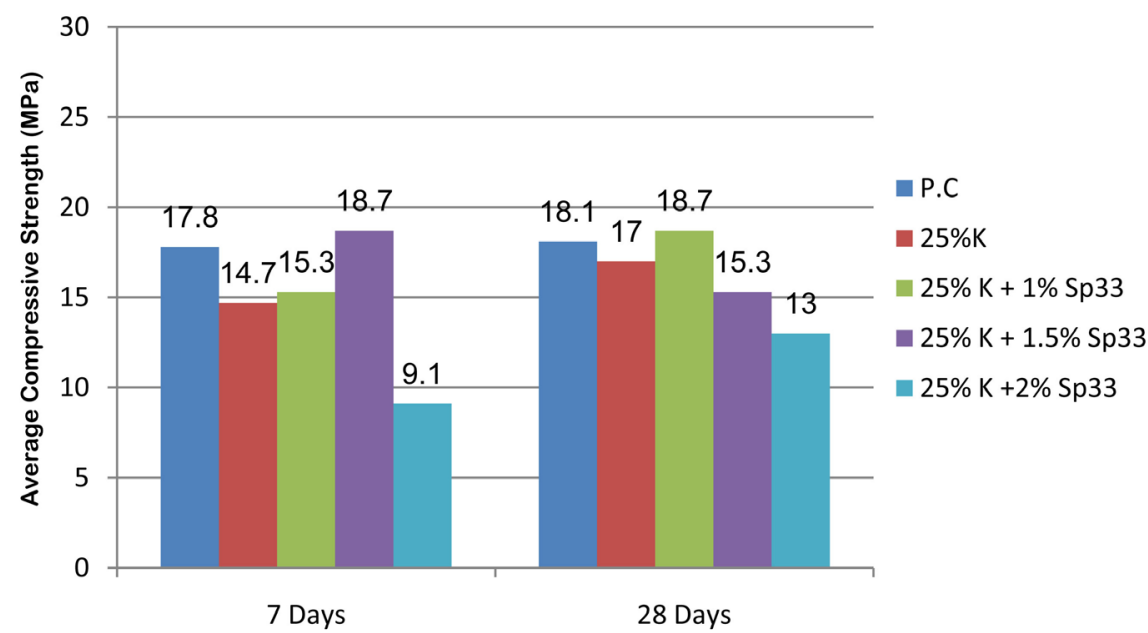

Figure 11. Compressive strength of SCC mixes with $25 \% \mathrm{~K}+$ different $\%$ SP33 dose compared with P.C at age 7 and 28 days for cylindrical specimens. 


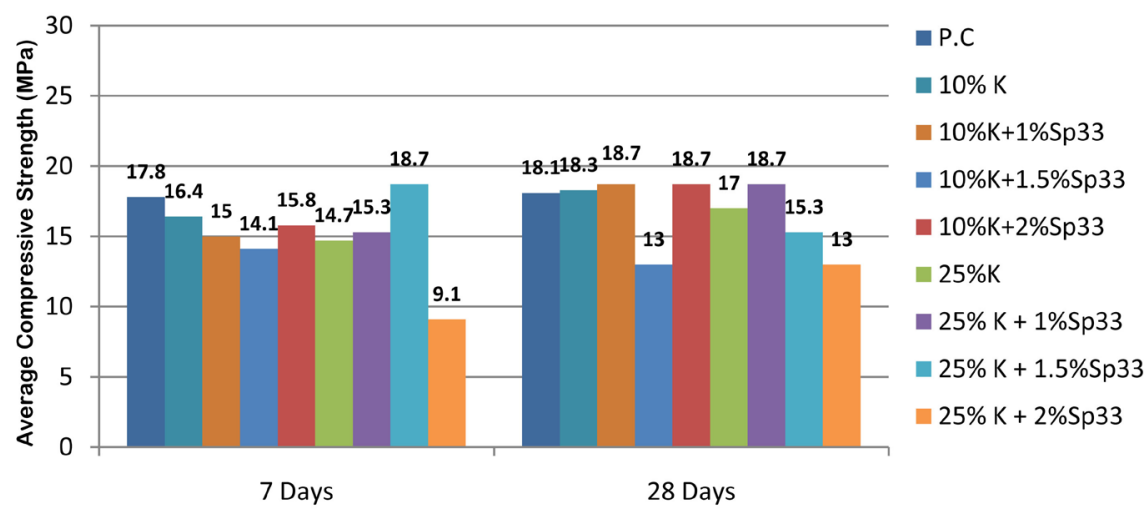

Figure 12. Compressive strength of various SSC mixes with different \% of al-khamkha and different $\%$ SP33 dose at age 7 and 28 days for cylindrical specimens.

observed for $(\mathrm{C}+10 \% \mathrm{~K}+2 \% \mathrm{SP} 33)$ mix. The compressive strength is decreased by $15.5 \%$ than PC mix.

At the age of 28 days, compressive strength of $\mathrm{PC}$ was $(18.3 \mathrm{MPa})$, and maximum compressive strength $(18.7 \mathrm{MPa})$ was observed for $(\mathrm{C}+10 \% \mathrm{~K}+1 \%$ SP33), $(C+10 \% \mathrm{~K}+2 \% \mathrm{SP} 33)$ and $(\mathrm{C}+25 \% \mathrm{~K}+1 \% \mathrm{SP} 33)$ mix. The compressive strength is increased by $2 \%$ over PC mix.

The compressive strength of the SCC cylindrical samples showed distinct values for the mix $(C+25 \% \mathrm{~K}+1 \%$ SP33) which had similar compressive strength as the $\operatorname{mix}(\mathrm{C}+10 \% \mathrm{~K}+1 \% \mathrm{SP} 33)$.

The lowered compressive strength value was achieved by the mix $(\mathrm{C}+25 \% \mathrm{~K}$ $+2 \%$ SP33) that had maximum percentage of replacement and maximum dose of SP33.The highest compressive strength in both kinds of samples was achieved by the mix $(\mathrm{C}+10 \% \mathrm{~K}+1 \% \mathrm{SP} 33)$.

Results of compressive strength for each $10 \% \mathrm{~K}$ and $25 \% \mathrm{~K}$ replacement mix compared to P.C compressive strength are summarized in Table 6 and Table 7.

\section{Conclusions}

In this experimental study both fresh and hardened properties of self compacting concrete produced from local available materials in Jordan were investigated. The SCC mixes were prepared both with and without al-khamkha waste with different doses of SP33 superplasticizer. Based on the results, it can conclude that it is possible to design self compacting concrete mix with different contents of locally available stone cut powder (al-khamkha) as partial replacement of fine silica aggregate. The effect of al-khamkha content and the SP33 dosages on fresh and hardened properties of SCC are listed below:

1) Different contents of al-khamkha as partial replacement of fine silica aggregate give different slump flow properties. The slump flow varied between the ranges of $340-730 \mathrm{~mm}$. It has been observed that the slump flow is decreased with increases of al-khamkha content, and as SP33 superplasticizer dosage increase the slump flow increase. 
Table 6. Compressive strength for each $10 \% \mathrm{~K}$ replacement SCC mix compared to P.C compressive strength.

\begin{tabular}{ccccc}
\hline \multirow{2}{*}{ Mix ID } & $\begin{array}{c}\text { Specimens } \\
\text { type }\end{array}$ & \multicolumn{2}{c}{ Compressive strength Age } & $\begin{array}{c}\text { 28 days compressive } \\
\text { strength deviation from }\end{array}$ \\
\cline { 3 - 4 } the control pure concrete
\end{tabular}

Table 7. Compressive strength for each $25 \% \mathrm{~K}$ replacement SCC mix compared to P.C compressive strength.

\begin{tabular}{|c|c|c|c|c|}
\hline \multirow{2}{*}{ Mix ID } & \multirow{2}{*}{$\begin{array}{l}\text { Specimens } \\
\text { type }\end{array}$} & \multicolumn{2}{|c|}{ Compressive strength Age } & \multirow{2}{*}{$\begin{array}{l}28 \text { days compressive strength deviation } \\
\text { from the control pure concrete }\end{array}$} \\
\hline & & 7 days $\mathrm{MPa}$ & 28 days $\mathrm{MPa}$ & \\
\hline \multirow{2}{*}{ P.C } & Cube & 18.7 & 19.8 & - \\
\hline & Cylinder & 17.8 & 18.1 & - \\
\hline \multirow{2}{*}{$\mathrm{C}+25 \% \mathrm{~K}$} & Cube & 16.9 & 21.2 & increased by $7.1 \%$ \\
\hline & Cylinder & 14.7 & 17 & decreased by $6.1 \%$ \\
\hline \multirow{2}{*}{$25 \% \mathrm{~K}+1 \% \mathrm{Sp}$} & Cube & 15.1 & 15.6 & decreased by $21.2 \%$ \\
\hline & Cylinder & 15.3 & 18.7 & increased by $3.3 \%$ \\
\hline \multirow{2}{*}{$25 \% \mathrm{~K}+1.5 \% \mathrm{Sp}$} & Cube & 17.6 & 18.1 & decreased by $8.6 \%$ \\
\hline & Cylinder & 18.7 & 15.3 & decreased by $15.5 \%$ \\
\hline \multirow{2}{*}{$25 \% \mathrm{~K}+2 \% \mathrm{Sp}$} & Cube & 12.4 & 15.2 & decreased by $23.2 \%$ \\
\hline & Cylinder & 9.1 & 13 & decreased by $28.2 \%$ \\
\hline
\end{tabular}

2) Al-khamkha as partial replacement of fine silica aggregate contributes to the harden property of SCC. The produced SCC developed compressive strengths ranging from (12.4 to $21 \mathrm{MPa}$ ) and from (15.2 to $25.5 \mathrm{MPa})$, at 7 and 28 days for cube specimens, and developed compressive strengths ranging between (9.1 to $17.8 \mathrm{MPa}$ ) and from (13 to $18.7 \mathrm{MPa}$ ), at 7 and 28 days for cylindrical specimens, respectively.

3) The SCC mix with $10 \%$ replacement of fine silica aggregate by al-khamkha together with $1 \%$ SP33 superplasticizer shows greater compressive strength as compared with other replacement levels. 


\section{References}

[1] Fakher, J.A. and Al Qinna, M.I. (2008) Marble Production and Environmental Constrains: Case Study from Zarqa Governorate, Jordan. Jordan Journal of Earth and Environmental Sciences, 1, 11-21.

[2] Felekoglu, B. (2007) Utilization of High Volumes of Limestone Quarry Waste in Concrete Industry (Self-Compacting Concrete Case). Resources, Conservation and Recycling, 51, 770-791. https://doi.org/10.1016/j.resconrec.2006.12.004

[3] Demirel, B. (2010) The Effect of the Using Waste Marble Dust as Fines and on the Mechanical Properties of the Concrete. International Journal of the Physical Sciences, 1372-1380.

[4] Brouwers, H.J.H. and Radix, H.J. (2005) Self-Compacting Concrete: Theoretical and Experimental Study. Cement and Concrete Research, 35, 2116-2136.

[5] Pala, K.P., Dhandha, K.J. and Nimodiya, P.N. (2015) Use of Marble Powder and Fly Ash in Self Compacting Concrete. International Journal for Innovative Research in Science \& Technology, 1, 475-479.

[6] Singh, Er.R., Kaushik, Er.R. and Singh, Er.G. (2013) Study of Self Compacting Concrete Using Brick Dust and Marble Powder. International Journal of Engineering Research and Applications, 2248-9622.

[7] Hameed, M.S., Sekar, A.S.S., Balamurugan, L. and Saraswathy, V. (2012) Self-Compacting Concrete Using Marble Sludge Powder and Crushed Rock Dust. KSCE Journal of Civil Engineering, 16, 980-988.

[8] Tayeb, B., Abdelbak, B., Madani, B. and Mohamed, L. (2011) Effect of Marble Powder on the Properties of Self-Compacting Sand Concrete. The Open Construction and Building Technology Journal, 5, 25-29. https://doi.org/10.2174/1874836801105010025

[9] Torres, P., Fernandes, H.R., Agathopoulos, S., Tulyaganov, D.U. and Ferreira, J.M.F. (2004) Incorporation of Granite Cutting Sludge in Industrial Porcelain Tile Formulations. Journal of the European Ceramic Society, 24, 3177-3185. https://doi.org/10.1016/j.jeurceramsoc.2003.10.039

[10] Turgut, P. and Algin, H.M. (2007) Limestone Dust and Wood Sawdust as Brick Material. Building and Environment Journal, 42, 3399-3403. https://doi.org/10.1016/j.buildenv.2006.08.012

[11] Ferreira, J.M.F., Torres, P.M.C., Silva, M.S. and Labrincha J.A. (2004) Recycling of Granite Sludge in Brick-Type and Floor Tile-Type Ceramic Formulation. Journal of the European Ceramic Society, 24, 3177-3185.

[12] Alzboon, K.K. and Mahasneh, K.N. (2009) Effect of Using Stone Cutting Waste on the Compression Strength and Slump Characteristics of Concrete. International Journal of Environmental Science and Engineering, 1, 167-172.

[13] Gsoglu, M., Güneyisi, E., Kocabag, M.E., Bayram, V. and Mermerdas, K. (2012) Fresh and Hardened Characteristics of Self Compacting Concrete Made with Combined Use of Marble Powder, Limestone Filler, and Fly Ash. Construction and Building Materials, 37, 160-170. 